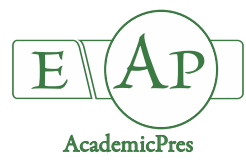

\title{
Alleviation of Salinity Stress in Maize Using Silicon Nutrition
}

\author{
Muhammad Mohsin RAZA ${ }^{1}$, Sami ULLAH ${ }^{2}$, Tariq AZIZ ${ }^{3}$, Tanveer ABBAS ${ }^{2}$, \\ Malik Muhammad YOUSAF ${ }^{1}$, Volkan ALTAY ${ }^{4}$, Munir OZTURK ${ }^{5 *}$ \\ ${ }^{1}$ Pakistan Agriculture Research Council, Arid Zone Research Institute Bahawalpur, \\ Pakistan;mohsinraza_5@yahoo.com;malikparc@gmail.com \\ ${ }^{2}$ Institute of Agricultural Resources and Regional Planning Chinese Academy of Agricultural Sciences Beijing 100081, \\ China; Samisheen14@yahoo.com; abbastanveer272@gmail.com \\ 3Institute of Soil and Environmental Sciences University of Agriculture Faisalabad, Pakistan; draziz@edu.uaf.pk \\ ${ }^{4}$ Hatay Mustafa Kemal University, Faculty of Science and Arts, Biology Department, Hatay, Turkey; volkanaltay34@gmail.com \\ ${ }^{5}$ Ege University, Science Faculty, Botany Department, Bornova, Izmir, Turkey; munirozturk@gmail.com (*corresponding author)
}

\begin{abstract}
Improving salinity tolerance through mineral nutrition in plants is emerging strategy for sustainable agriculture under limited resources. Silicon $(\mathrm{Si})$ is considered as silver bullet to mitigate biotic and abiotic stresses. Present study was conducted to understand the new mechanisms of Si nutrition against salinity stress in two different maize (Zea mays L.) cultivars ('Syngenta-8441' and 'Pearl'). Three different levels of $\mathrm{NaCl}\left(0.67,8\right.$ and $\left.13 \mathrm{dSm}^{-1}\right)$ were used with and without addition of silicic acid $(2 \mathrm{mM})$. Distilled water was used for irrigation purposes and crop was harvested after 40 days of post germination. Results indicated that plant biomass reduced under saline condition while Si application increased growth parameters. Data regarding chemical analysis showed that $\mathrm{Si}$ nutrition reduced $\mathrm{Na}^{+}$concentration and enhanced $\mathrm{K}^{+}$levels in root, shoot, new and old leaves of 'Sygenta 8441' compared to 'Pearl' maize variety. Si application improved both chlorophyll a and b in both maize cultivars compared to $\mathrm{NaCl}$-treated plants. The current findings indicate that $\mathrm{Si}$ nutrition can alleviate salinity stress in maize without decreasing growth attributes of crop and 'Sygenta 8441' is a salt resistant variety whereas 'Pearl' is a salt sensitive variety.
\end{abstract}

Keywords: alleviation; plant growth; salinity; silicon nutrition; Zea mays

\section{Introduction}

Food security is a serious issue in developing countries with ever-increasing population. Recent estimates show that in 2017, 821 million people have suffered from under nourishment due to poverty and/or natural calamities (FAO, 2018). Land degradation occurs mainly due to various abiotic factors like drought, salinity, and pollution. Among various abiotic stresses, soil salinity poses a serious threat to the agriculture around the globe (Ghassemi et al., 1995; Ozturk et al., 2006; Chedlly et al., 2008; Ashraf et al., 2012; Hakeem et al., 2013; Hameed et al., 2019). Salinity is associated with ion toxicity and physiological drought to plants (Acosta-Motos et al., 2015). In most cases, $\mathrm{Na}^{+}$and $\mathrm{Cl}^{-}$ions are the cause of salinity. The $\mathrm{Na}^{+}$and $\mathrm{Cl}^{-}$induce salinity stress which usually leads to reduced plant growth rate together with nutrition imbalance, and at higher concentrations cause leaf scorching, chlorosis and necrosis (Munns and Tester, 2008; Ashraf et al., 2010). Salt stress condition affects physiology of plants by changing water and ionic balance of plant cells, nitrogen and carbon dioxide assimilation rates as well as protein biosynthesis mechanisms (Cusido et al., 1987; Shannon and Grieve, 1999; Wahid et al., 1999; Hasegawa et al., 2000). Yield, plant biomass as well as quality of the product are severely affected negatively due to instability of plant between organic and inorganic ingredients (Gunes et al., 1996, 2007; Nasim et al., 2008). Reduced plant growth due to salt-stressed condition depends upon amount of salt present in soil, type of specific salt and plant affected plant tissues (Munns and Tester, 2008). Mostly excess salt concentration species $\left(\mathrm{Na}^{+}\right.$and $\mathrm{Cl}$ ) damage plant root membranes effecting selectivity mechanism of the membrane followed by an adverse effect on potassium balance, decrease in nitrogen assimilation enzyme activity (nitrate reductase), inhibition of photo system II (Gadallah, 1999) and chlorophyll breakdown 
(Ball et al., 1987, Hasegawa et al., 2000). Judicious use of mineral nutrition such as high potassic fertilizers (Raza et al., 2006) and osmo-protectant applications (Arfan et al., 2007) are healthy strategies as these strengthen the plant to cope against salt stress but cannot be used for long time for permanent amelioration. Some researchers have also used hormones like abscisic acid (ABA) and natural acid including jasmonic acid (JA) for higher growth and yield under salt stressed condition, but these approaches are not feasible for common farmers due to the expensiveness of hormones and acids (Gautam and Singh, 2009; Hayat et al., 2010; Singh and Gautam, 2013).

Silicon ( $\mathrm{Si}$ ) has considerable ameliorative features against $\mathrm{Na}^{+}$and $\mathrm{Cl}^{-}$toxicity, as it allows plants to grow more effectively on saline soils, which appears to be of economic gain primarily for industrializing countries. It improves plant growth especially under abiotic stresses and reduces radiation effects as well as water loss up to 30 percent ( Dionisio-Sese and Tobita, 1998). Si uptake by plant under salinity increases root activity and inhibits transpiration but increases the activity of ATPase and PPase in plasma membrane, there by leading to an increase in the $\mathrm{K}$ and decreases Na uptake (Liang et al., 2007; Khan et al., 2018).

In Pakistan, maize (Zea mays L.) is an important profitable crop after potato and its growth and yield are highly retarded as a glycophyte as the soil salinity increases. However, availability of $\mathrm{Si}$ in the growth medium hinders the salinity effect by changing soil/plant factors, but specific mechanisms are still debatable (Tariq and Iqbal, 2010; Kafi and Rahimi, 2011; Khan et al., 2003, 2018). Data on the role of $\mathrm{Si}$ in alleviating the salinity stress effects on maize has not been explained at length. Silicon nutrition management increases growth of maize following salt stress. Present study was planned with following objectives: 1) to compare the two maize cultivars ('Syngenta-8441' and 'Pearl') against salinity stress and evaluate the role of $\mathrm{Si}$ in improving salinity stress tolerance, 2) to investigate the Si effects on ionic concentration under salinity stressed maize plants.

\section{Materials and Methods}

\section{Experimental details}

A portion of prepared soil was analysed for various physico-chemical characteristics (Table 1) according to the U.S. salinity Lab. Staff (1954). Ten kg polyethylene lined plastic pots were filled with soil and whole experiment was set under completely randomized design with factorial arrangement. Chemical fertilizers were applied as N, P and $\mathrm{K} 270-160-90 \mathrm{~kg} \mathrm{ha}^{-1}$, before sowing as urea, diammonium phosphate and single super phosphate respectively. Natural salt $\mathrm{NaCl}$ was applied at 0 and $60 \mathrm{mM}$ in solution form for maintaining salinity levels. After fertigation of NPK fertilizers and salt, the soil in each pot was remixed to make it homogenized. Silicic acid was applied at different rates $(0$ and $2 \mathrm{mM}$ ) as Si source and mixed well in each pot. 'Syngenta-8441'-salt tolerant and 'Pearl'-salt sensitive maize cultivars were selected for this experiment and distilled water was applied as irrigation water whenever needed. Ten seeds were sown in each pot and after successful germination; six plants out of ten were uprooted and incorporated into the soil of same pot.
Agronomic and physiological parameters

Agronomic parameters of maize including root and shoot fresh weight; root and shoot dry weight, plant height and plant weight were calculated by following standard procedures (Naveed et al., 2014). Fresh weight was measured after harvesting while dry weight was computed after oven drying until constant weight with electronic balance. Chlorophyll a and b were measured by the method outlined by Strain and Svec (1966). Upper $3^{\text {rd }}$ fully expanded leaf was selected and harvested after 40 days of germination, $1 \mathrm{~g}$ of this was ground in 90 percent acetone manually using pestle and mortar, absorbance was measured with UV/visible spectrophotometer (Shimadzu, UV-1201, Kyoto, Japan) and chlorophyll concentration calculated as given by Khan et al. (2018).

\section{Plant chemical analysis}

The plants harvested after 40 days of germination were washed twice with distilled water, blotted dry with tissue paper and subjected to chemical analysis. Samples were airdried and then oven dried at $65^{\circ} \mathrm{C}$ for two days till constant weight. For determination of $\mathrm{Na}^{+}$and $\mathrm{K}^{+}$concentrations, samples were grinded with the help of grinder (IKA Werke). Both were measured in the root, shoot, old and young leaves using flame photometer (Jenway PFP-7, England) and concentrations calculated by calibration curve (Naveed et al., 2014). For Si determination 0.5 g grounded samples were digested in $2 \mathrm{~mL} 50$ percent hydrogen peroxide $\left(\mathrm{H}_{2} \mathrm{O}_{2}\right)$ and $4.5 \mathrm{~g} 50$ percent $\mathrm{NaOH}$ in teflon beakers on a hot plate at $150^{\circ} \mathrm{C}$ for 4 hours. Silicon concentration was measured as given by Elliot and Synder (1991) and absorbance measured at $650 \mathrm{~nm}$ wave length with a UV visible spectrophotometer (Shimdzu, Spectronic 100, Japan) (Ali et al., 2012).

\section{Statistical analysis}

Main and interactive effects of silicon, salinity and genetic variability were analyzed on various response variables by analysis of variance (ANOVA) technique. Least significant difference (LSD) test was used to determine significantly different treatment means (Steel et al., 1997). Statistix 8.1 (Analytical Software, Tallahassee, USA) and Microsoft Excel ${ }^{\oplus}$ (Microsoft Cooperation, USA) were used for statistical analysis.

\section{Results and Discussion}

\section{Agronomic and physiological parameters}

Data regarding agronomic parameters has shown that $\mathrm{Si}$ application improves plant growth while salinity suppresses the plant growth parameters. Data has revealed that salinity stress decreased plant fresh weight in 'Pearl' variety up to 28 $\mathrm{g}$ as compared to the controls (87.33 g), but Si application alone increased plant weight up to $107 \mathrm{~g}$. Similar trend was observed for 'Sygenta 8441' with minute differences. The dry plant weight has shown the same trend as fresh weight in both maize varieties. Root fresh and dry weight was nonsignificant in main as well as in interaction effects, but $\mathrm{Si}$ application improved it as compared to salt stress condition (Fig. 1). Maximum and minimum plant height (65 and $28.78 \mathrm{~cm}$ ) was recorded with $\mathrm{Si}$ applied singly and under 
1342

Table 1. Physico-chemical properties of soil used for experiment before amendment

\begin{tabular}{cc}
\hline $\mathrm{pHs}$ & 7.89 \\
Electrical Conductivity $(\mathrm{ECs})\left(\mathrm{dS} \mathrm{m}^{-1}\right)$ & 0.67 \\
Cation Exchange Capacity $(\mathrm{CEC})\left(\mathrm{cmolc} \mathrm{kg}^{-1}\right)$ & 14.80 \\
$\mathrm{Cl}^{-}\left(\mathrm{mmolc} \mathrm{L}^{-1}\right)$ & 13.60 \\
$\mathrm{SO}^{-2}\left(\mathrm{mmolc} \mathrm{L}^{-1}\right)$ & 10.11 \\
$\mathrm{Ca}^{+2}+\mathrm{Mg}^{+2}\left(\mathrm{mmolc} \mathrm{L}^{-1}\right)$ & 8.60 \\
$\mathrm{Na}^{+}\left(\mathrm{mmolc} \mathrm{L}^{-1}\right)$ & 15.68 \\
\hline Organic Matter $(\mathrm{OM})(\%)$ & 7.76 \\
$\mathrm{~N}(\%)$ & 0.85 \\
$\mathrm{Olsen} \mathrm{P}^{\mathrm{P}}\left(\mathrm{mg} \mathrm{kg}^{-1}\right)$ & 0.03 \\
$\mathrm{~K}\left(\mathrm{mg} \mathrm{kg}^{-1}\right)$ & 7.80 \\
\hline
\end{tabular}

salt stressed condition in 'Sygenta' variety. A combined application of $\mathrm{Si}$ and natural salt has improved plant height up to 44.87 and $42 \mathrm{~cm}$ in 'Sygenta' and 'Pearl' varieties respectively and it was significantly higher than salt stressed condition (Fig. 2). The root length data shows that $\mathrm{Si}$ application significantly improves root length in both maize varieties as compared to either in saline condition or combined application of $\mathrm{Si}$ and salt. Salinity stress reduces both chlorophyll $\mathrm{a}$ and $\mathrm{b}$ in both maize verities compared to $\mathrm{Si}$ applied singly or as $\mathrm{Si}+\mathrm{NaCl}$. In the case of chlorophyll a maximum value was recorded from $\mathrm{Si}$ applied singly $(0.49$ ug $\mathrm{g}^{-1}$ ) followed by control for 'Pearl', same trend was observed for 'Sygenta' variety. $\mathrm{Si}+\mathrm{NaCl}$ application has improved chlorophyll b up to $0.70 \mathrm{ug} \mathrm{g}^{-1}$ in 'Sygenta', which was non-significant to $\mathrm{Si}$ applied singly and control treatments; but in 'Pearl' variety $\mathrm{Si}$ application applied singly has enhanced chlorophyll b up to $0.80 \mu \mathrm{g} \mathrm{g}^{-1}$. Salinity has reduced all growth and physiological maize attributes of both cultivars but $\mathrm{Si}$ application has improved all these parameters even under salt stressed condition (Fig. 3).

Salinity stresses negatively affect plant growth and yield. $\mathrm{NaCl}$ is the major salt in salt affected soils, which not only reduces population of plants in the field but also decreases plant biomass and increases production cost in such areas. Maize crop is more sensitive to salinity at early growth stages compared to later stages. In this experiment all the growth parameters including plant biomass, plant height and root length decreased under saline condition but enhanced when the experimental plants were Si- treated. Our findings are in full agreement with those published by Moussa (2005), Kafi and Rahimi (2011) and Parveen and Ashraf (2010). The possible mechanism may be the reduction in cell membrane integrity under salt stressed condition (Marschner, 1995). Interestingly, no significant effect was observed in the case of dry matter yield in both varieties (Fig. 1), but possible mechanism may vary from genotype to genotype even within a species. Plant biomass and plant height might be reduced due to less cell expansion under salt stressed condition due to the presence of $\mathrm{Na}^{+}$in soil solution (Khan et al., 2018). Si taken by plants acts as detoxicant against $\mathrm{Na}^{+}$in cell wall of plant and binds to the cell wall instead of $\mathrm{Na}^{+}$resulting in a decrease in its movement towards shoots and leaves (Khan et al., 2017,2018). Both chlorophyll a and $\mathrm{b}$ measured here were less under salt stressed condition compared to Si application treatment. The decrease in chlorophyll concentration might be due to improper working of photosynthetic mechanism (Mateos-Naranjo $e t$ al., 2013) or may be due to production of destructive enzymes such as chlorophyllase produced in the plants under stressed conditions, which leads to the degradation of chlorophyll apparatus (Sabater and Rodriquez, 1978) or due to production of reactive oxygen species (Moussa, 2005). Si application has improved chlorophyll levels as recorded in this study, because it might have detoxifying effect on ROS (Fig. 2). Our results are in full agreement with those of Wang et al. (2015).

\section{Ionic concentration}

The results regarding the chemical analysis are more prominent than growth parameters following application with or without Si. The concentrations of potassium and sodium were measured in young and old leaves as well as in root and shoot. In young leaves maximum $\mathrm{K}$ concentration $\left(0.56 \mathrm{mg} \mathrm{g}^{-1}\right)$ was recorded in 'Sygenta 8441' variety with just $\mathrm{Si}$ application and it was greater than even control treatment. $\mathrm{Si}+\mathrm{NaCl}$ application did not improve $\mathrm{K}$ concentration significantly in young leaves compared to salt stress condition in both cultivars. In older leaves, $\mathrm{K}$ concentration difference in main and interaction effects was non-significant for all treatments in both cultivars (Fig. 4). The results were reverse regarding $\mathrm{K}$ concentration in root of both verities. Salinity reduced $\mathrm{K}$ uptake in root while Si application enhanced $\mathrm{K}$ levels in $\mathrm{Si}$ treatment given alone and $\mathrm{Si}+\mathrm{NaCl}$ applied up to 12.10 and $10.16 \mathrm{mg} \mathrm{g}^{-1}$ in 'Pearl' variety; similar trend was recorded for other maize variety with small differences. Na uptake was also significantly reduced with $\mathrm{Si}$ application in both verities, but most prominent effect was observed in the 'Pearl' compared to 'Sygenta 8441'. Minimum Na level in young and old leaves $\left(0.08\right.$ and $\left.0.09 \mathrm{mg} \mathrm{g}^{-1}\right)$ was recorded in control treatment (no salt application) followed by $\mathrm{Si}$ applied alone in 'Sygenta' and 'Pearl' varieties respectively, both treatments were statistically non-significant. Maximum $\mathrm{Na}$ concentration was found in the treatment where $\mathrm{NaCl}$ was applied alone in both old and young leaves in both verities. Comparatively more $\mathrm{Na}$ concentration was recorded in root as compared to shoot under salt stress condition in both the varieties compared to young and old leaves. With Si application Na concentration in roots was reduced up to 50 percent compared to saline condition in 'Sygenta 8841' variety; $\mathrm{Na}$ concentration decreased by 43 percent compared to the control treatment. 

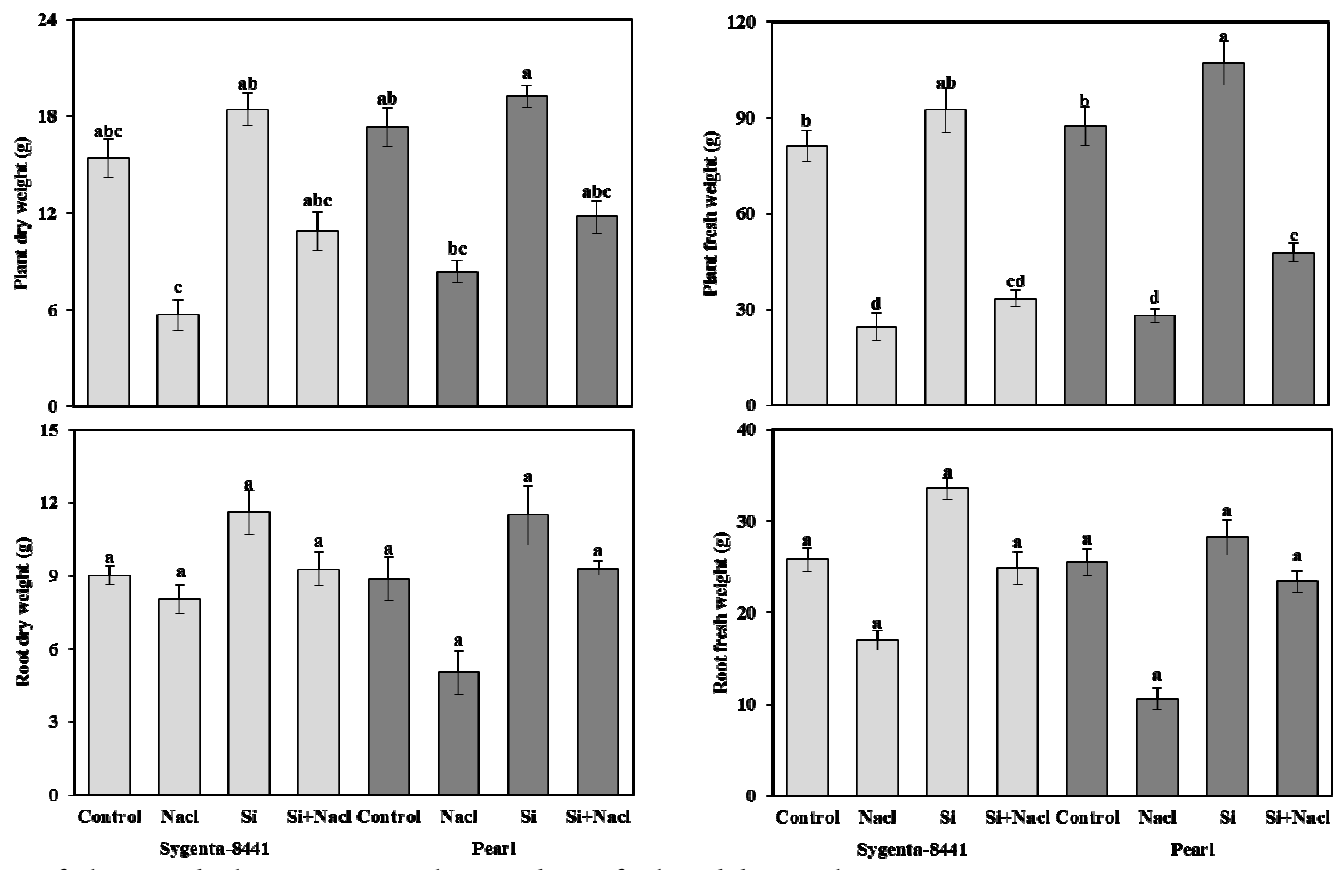

Fig. 1. Effect of silicon and salinity on maize shoot and root fresh and dry weight
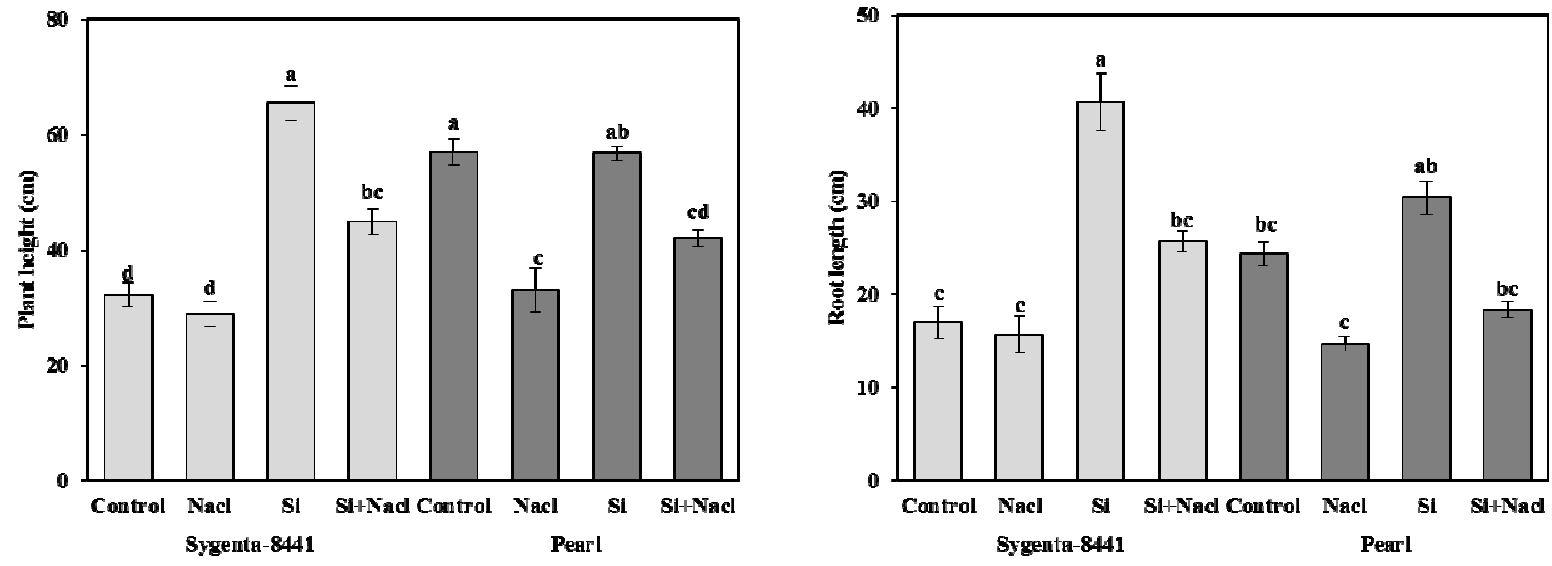

Fig. 2. Plant height influenced by silicon nutrition under salt stressed condition
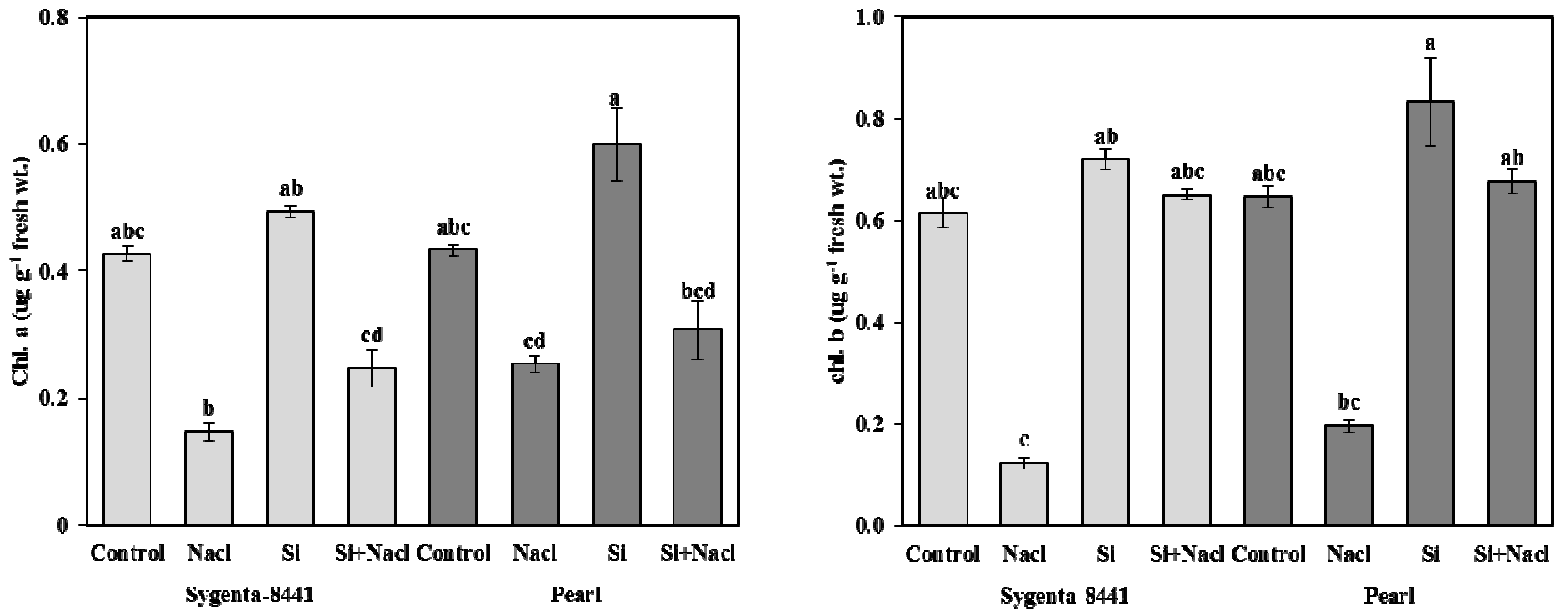

Fig. 3. Effect of silicon nutrition and salinity on chlorophyll content 
1344

$\mathrm{Na}$ concentration in the roots of 'Pearl' variety was higher compared to 'Sygenta 8441' under salt stressed condition. Similar trend was recorded for $\mathrm{Na}$ concentration in shoot in both maize cultivars with minor differences (Fig. 5).

Si concentration in shoot as well as root was statistically different due to application of $\mathrm{Si}$ in both verities. Maximum $\mathrm{Si}\left(8.33 \mathrm{mg} \mathrm{kg}^{-1}\right)$ was monitored in 'Sygenta 8441 ' variety where $\mathrm{Si}$ was applied singly followed by $\mathrm{Si}+\mathrm{NaCl}$ application. Under salt stressed condition 1.3 and $1.7 \mathrm{mg} \mathrm{kg}$ ${ }^{1} \mathrm{Si}$ were recorded in shoot of 'Sygenta 8441' and 'Pearl' varieties respectively. Si concentration in roots was higher compared to shoots in both varieties for salt stressed as well as other treatments. $\mathrm{Si}+\mathrm{NaCl}$ combined application increased $\mathrm{Si}$ level in root up to 8 and $7.66 \mathrm{mg} \mathrm{kg}^{-1}$ root dry weight and these values were statistically non-significant for both maize cultivars when Si was applied singly (Fig. 6).

$\mathrm{Na}$ concentration was higher under salt stressed soil condition and $\mathrm{K}$ is low in the plants grown on saline soils. The basic mechanism behind this might be less integrity of plant cell membrane resulting in leaking of $\mathrm{K}$ ions while maintaining $\mathrm{Na}$ ions in plant body (Marschner, 1995). The increase of $\mathrm{Na}$ concentration either in leaves, roots or shoots damages cells and ultimately causes cell death (Parida and Das, 2005). In our experiment salt tolerance maize variety 'Sygenta 8441' and salt sensitive variety 'Pearl' have shown that ionic $\mathrm{Na}$ concentration was higher in 'Pearl' as
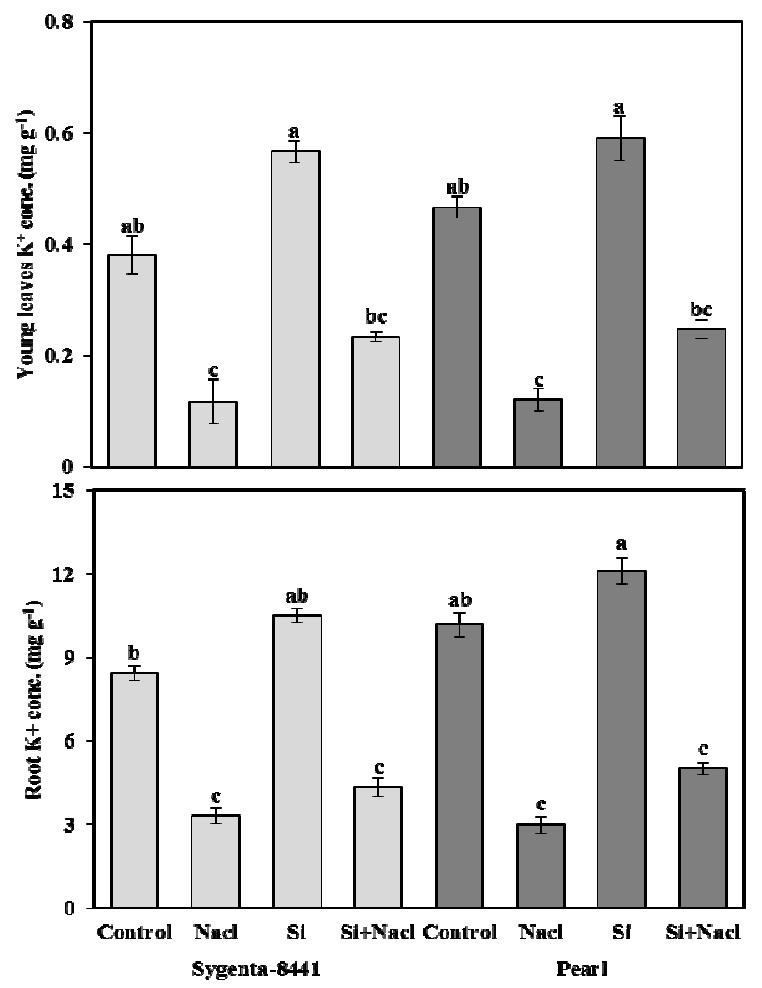

compared less Na concentration recorded in 'Sygenta 8441'. It is well known now that salt resistant verities accumulate less $\mathrm{Na}$ in tissues and our findings coincide with these results (Aktas et al., 2006; Khan et al., 2017). Si-treated plants have shown more promising results regarding growth and other parameters compared to salt stressed plants. Si present in the plant protects them against physical injury as well as cell destructing ions $\left(\mathrm{Na}^{+}\right)$which are converted into more stable form under salt stress condition (Khan et al., 2018). Low concentration of reactive oxygen species (ROS) are necessary for plant metabolism and signaling but higher concentration causes autocatalysis of lipid membranes (Xu et al., 2006; Choudhury et al., 2013). Under salt stressed condition, more ROS is produced inside the plant resulting in weakening of cell membrane. Si application induces salinity tolerance in plants probably via regulation of ROS under salt stressed condition (Zhang et al., 2006; Rouhier and Jacquot, 2008). In this study, higher Na concentration was noted in salt stressed plants compared to $\mathrm{Si}$ or $\mathrm{Si}-\mathrm{NaCl}$ treated plants (Fig. 5). Therefore, we conclude that under salt stressed condition excessive amount of $\mathrm{NaCl}$ in soilplant system leads to a reduction in the intra cellular water, as such compatible solutes including organic as well as inorganic solutes accumulate in cytoplasm of cell to maintain turgidity of cell resulting in higher concentration of $\mathrm{Na}^{+}$and $\mathrm{Cl}^{-}$in shoot (Ahmad and Prasad, 2011).

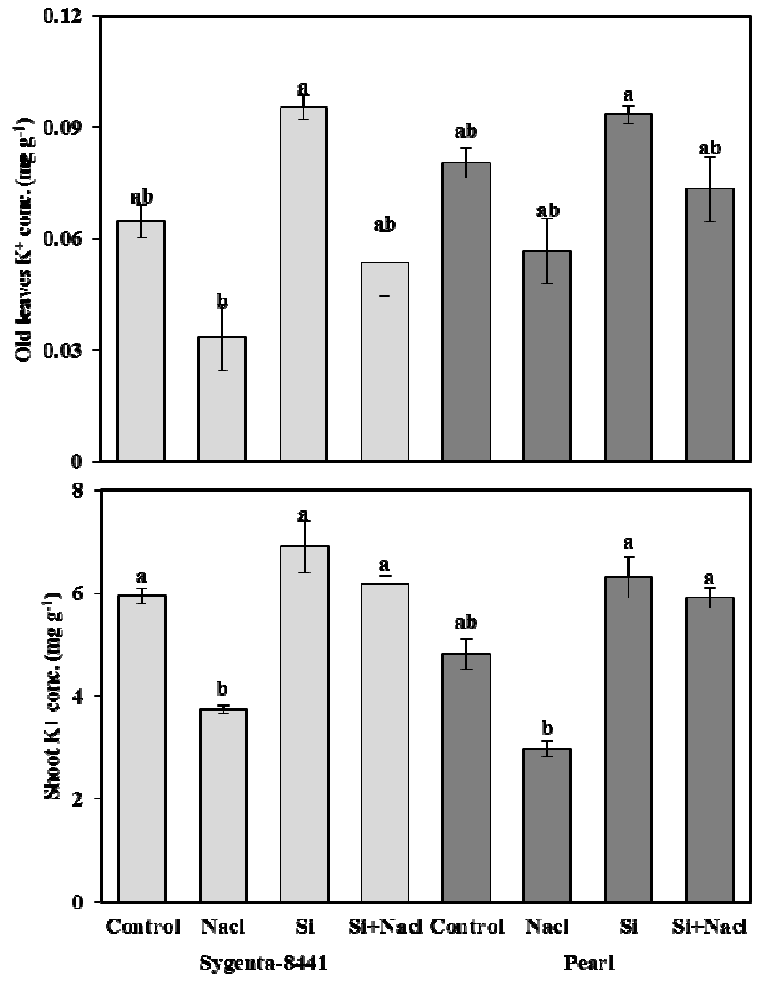

Fig. 4. Concentration of $\mathrm{K}^{+}$in root, shoot and leaves as affected by silicon application under salinity condition 

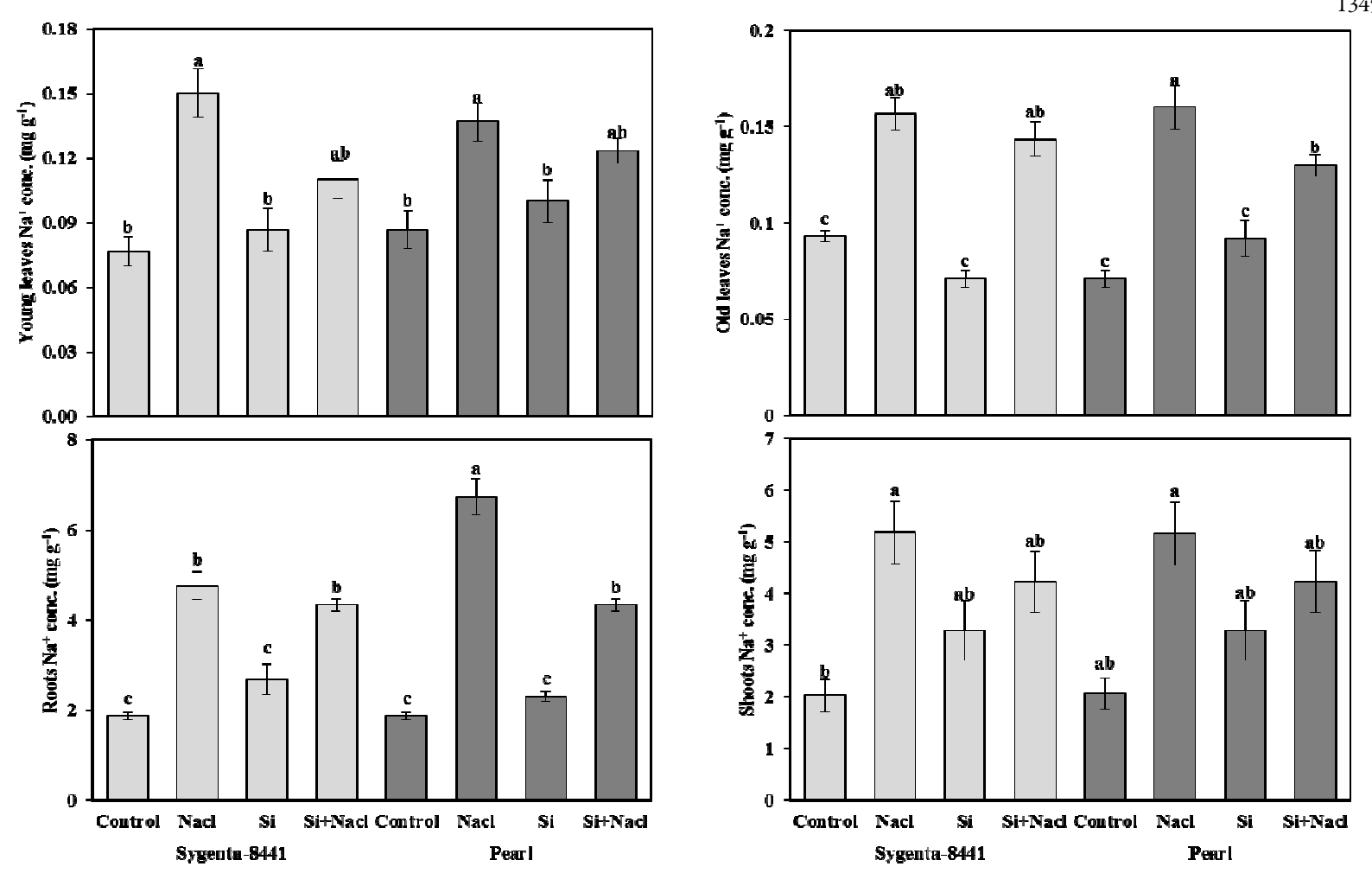

Fig. 5. Concentration of $\mathrm{Na}^{+}$in root, shoot and leaves as affected by silicon application under salinity condition
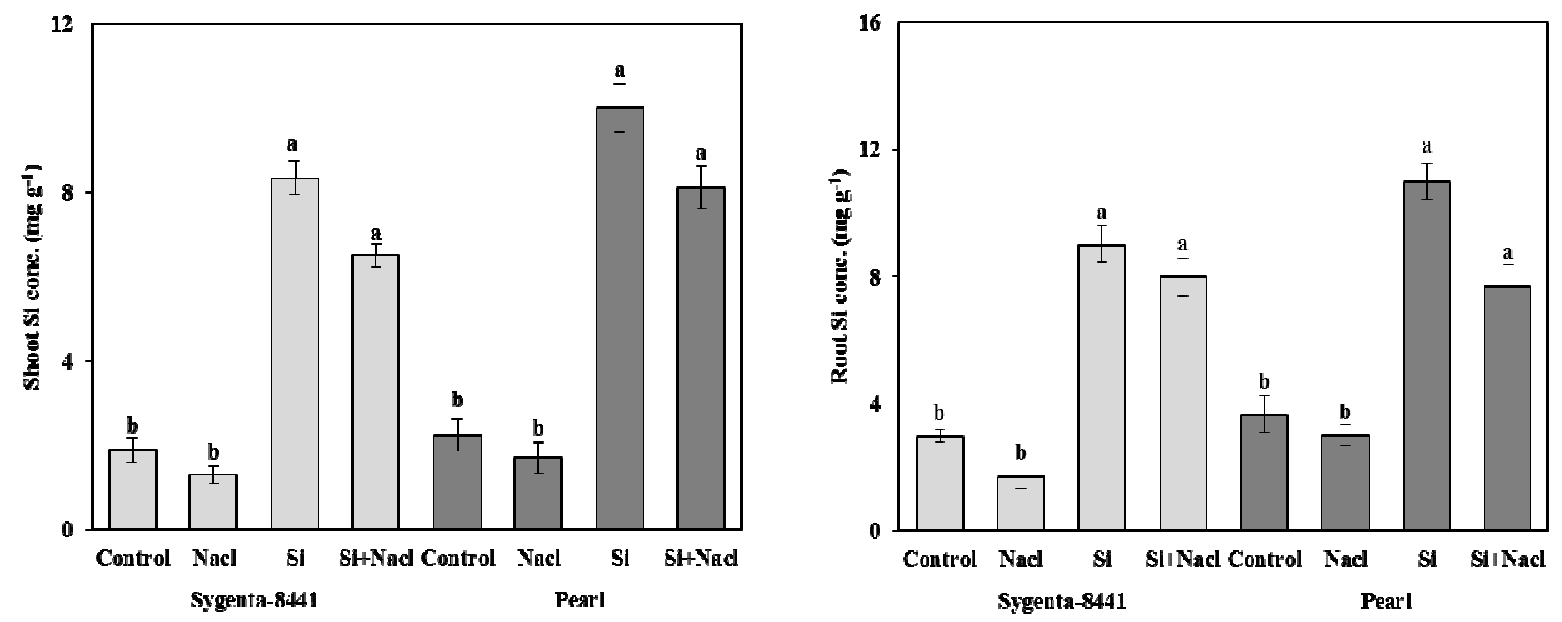

Fig. 6. Silicon concentration in root and shoot of maize plant under salt stressed environment

\section{Conclusions}

The area of salt affected soils is increasing day by day due to various reasons. These are resulting in the decrease in crop growth and yield. In the present study, $\mathrm{NaCl}$ has been observed to affect both maize varieties ('Sygenta 8441' and 'Pearl') negatively, with little or more difference. However, $\mathrm{Si}$ application has enhanced growth of plants. Si applied singly has proved more prominent compared to $\mathrm{Si}-\mathrm{NaCl}$ treated plants, but both treatments were statistically significant than $\mathrm{NaCl}$ applied alone.

\section{Acknowledgements}

Authors are thankful to the Institute of Soil and Environmental Sciences (ISES), University of Agriculture Faisalabad for providing space and other necessary material for conducting this research.

Our thanks are also due to the Hatay Mustafa Kemal University and Ege University for allowing us to collaborate with their staff during this project. 
1346

\section{Conflict of Interest}

The authors declare that there are no conflicts of interest related to this article.

\section{References}

Acosta-Motos JR, Diaz-Vivancos P, Álvarez S, Fernández-García N, Sanchez-Blanco MJ, Hernández JA (2015). Physiological and biochemical mechanisms of the ornamental Eugenia myrtifolia L. plants for copingwith $\mathrm{NaCl}$ stress and recovery. Planta 242(4):829-846.

Ahmad P, Prasad MNV (2011). Environmental adaptations and stress tolerance of plants in the era of climate change. Springer Science and Business Media.

Aktas H, Abak K, Cakmak I (2006). Genotypic variation in the response of pepper to salinity. Scientia Horticulturae 110(3):260-266.

Ali A, Basra SM, Iqbal J, Hussain S, Subhani MN, Sarwar M, Haji A (2012). Silicon mediated biochemical changes in wheat under salinized and nonsalinized solution cultures. African Journal of Biotechnology 11(3):606 615.

Arfan M, Athar HR, Ashraf M (2007). Does exogenous application of salicylic acid through the rooting medium modulate growth and photosynthetic capacity in two differently adapted spring wheat cultivars under salt stress? Journal of Plant Physiology 164(6):685-694.

Ashraf M,Afzal M,Ahmed R, Mujeeb F, Sarwar A, Ali L (2010). Alleviation of detrimental effects of $\mathrm{NaCl}$ by silicon nutrition in salt Esensitive and Etolerant genotypes of sugarcane (Saccharum officinarum L.). Plant Soill 326(12):381-391.

Ashraf M, Ozturk M, Ahmad MSA, Aksoy A (2012). Crop production for agricultural improvement. Springer Science+Business Media, NY.

Ball MC, Chaw WS, Anderson JM (1987). Salinity induced potassium deficiency causes loss of functional photosystem II in leaves of the grey mangrove, Avicennia marina, through depletion of the atrazine-binding polypeptide. Australian Journal of Plant Physiology 14(3):351-361.

Chedlly A, Ozturk M, Ashraf M, Grignon C (2008). Biosaline agriculture and high salinity tolerance. Birkhauser Verlag(Springer Science), Basel.

Choudhury S, Panda P, Sahoo L, Panda SK (2013). Reactive oxygen species signaling in plants under abiotic stress. Plant Signaling and Behavior 8(4):e23681.

Cusido RM, Palazon J, Altabella T, Morales C (1987). Effect of salinity on soluble protein, free amino acids and nicotine contents in Nicotiana rustica L. Plant and Soil 102(1):55-60.

Dionisio-Sese ML, Tobita S (1998). Antioxidant responses of rice seedlings to salinity stress. Plant Science 135(1):1-9.

Elliott CL, Snyder GH (1991). Autoclave-induced digestion for the colorimetric determination of silicon in rice straw. Journal of Agricultural and Food Chemistry 39(6):1118-1119.

FAO (Food and Agriculture Organization of the United Nations). The Food and Agriculture Organization Corporate Statistical Database. Retrieved 2018May 05 from http://wwwfaostat3fao.org.

Gadallah MAA (1999). Effects of proline and glycinebetaine on Vicia faba responses to salt stress. Biologia Plantarum 42(2):249-257.

Gautam S, Singh PK (2009). Salicylic acid-induced salinity tolerance in corn grown under $\mathrm{NaCl}$ stress. Acta Physiologiae Plantarum 31(6):1185.

Ghassemi F, Jakeman AJ, Nix HA (1995). Salinisation of land and water resources: human causes, extent, management and case studies. $\mathrm{CAB}$ International.

Gunes A, Ilnal A, Alpaslan M(1996). Effect of salinity on stomatal resistance, proline and mineral composition of pepper. Journal of Plant Nutrition 9(2):389-396.

Gunes A, Inal A, Alpaslan M, Eraslan F, Bagci EG, Cicek N (2007). Silicic acid induced changes on some physiological parameters symptomatic for oxidative stress and mineral nutrition in maize (Zea mays $\mathrm{L}$.) grown under salinity.Journal of Plant Physiology 164(6):728-736.

Hakeem KR, Parvaiz A, Ozturk M (2013). Crop improvement-new approaches and modern techniques. XXVII, Springer Science+Business Media,NY.

Hameed M, Ahmad MSA, Ashraf M, Ozturk M, Fatima S (2019). Plant genetic resources of major and minor crops: origin, sustainable use, and conservation. In: Öztürk M et al. (Eds). Crop production technologies for sustainable use and conservation-physiological and molecular advances. Apple Academic Press Inc. USA, pp 1-44.

Hayat Q, Hayat S, Irfan M, Ahmad A (2010). Effect of exogenous salicylic acid under changing environment: a review. Environmental and Experimental Botany 68(1):1425.

Hasegawa PM, Bressan RA, Zhu JK, Bohnert HJ (2000). Plant cellular and molecular response to high salinity. Annual Review of Plant Physiology and Plant Molecular Biology 51(1):463-499.

Kafi M, RahimiZ (2011).Effect of salinity and silicon on root characteristics, growth, water status, proline content and ion accumulation of purslane (Portulacaoleracea L.). Soil Science and Plant Nutrition 57(2):341-347.

Khan AA, Rao SA, Mcneilly T (2003). Assessment of salinity tolerance based upon seedling root growth response functions in maize (Zea mays L.).Euphytica 131(1):81-89.

Khan WUD, Aziz T, Hussain I, Ramzani PMA, Reichenauer TG (2017). Silicon: a beneficial nutrient for maize crop to enhance photochemical efficiency of photosystem II under salt stress. Archives of Agronomy and Soil Science 63(5):599-611.

Khan WUD, Aziz T, Maqsood MA, Farooq M, Abdullah Y, Ramzani PMA, Bilal HM (2018). Silicon nutrition mitigates salinity stress in maize by modulating ion accumulation, photosynthesis, and antioxidants. Photosynthetica 56(4):1047-1057.

Liang Y, Sun W, Zhu YG, Christie P (2007). Mechanisms of siliconmediated alleviation of abiotic stresses in higher plants: A review. Environmental Pollution 147(2):422-428.

Marschner H (1995). Mineral nutrition of higher plants. London: Academic Press.

Mateos-Naranjo E, Andrades-Moreno L, Davy AJ (2013). Silicon alleviates deleterious effects of high salinity on the halophytic grass Spartina densiflora. Plant Physiology and Biochemistry 63:115-121.

Moussa HR (2005). Influence of exogenous application of silicon on physiological response of salt-stressed maize (Zea mays L.). International Journal of Agriculture and Biology 8(3):293-297.

Munns R, Tester M (2008). Mechanisms of salinity tolerance. Annual Review of Plant Biology 59:651-681.

Nasim M, Qureshi R, Aziz T, Saqib M, Nawaz S, SahiST, Pervaiz S (2008). 
Growth and ionic composition of salt-stressed Eucalyptus camaldulensis and Eucalyptus teretcomis. Pakistan Journal of Botany 40(2):799-805.

Naveed M, Mitter B, Reichenauer TG, Wieczorek K, Sessitsch A (2014). Increased drought stress resilience of maize through endophytic colonization by Burkholderia phytofirmans PsIN and Enterobacter sp. FD17.Environmental and Experimental Botany 97:30-39.

Ozturk M, Waisel Y, Khan MA, Gork G (2006). Biosaline agriculture and salinity tolerance in plants. Birkhauser Verlag(Springer Science), Basel.

Parida AK, Das AB (2005). Salt tolerance and salinity effects on plants: a review.Ecotoxicology and Environmental Safety 60(3):324349.

Parveen N, Ashraf M (2010). Salinity tolerance of three range grasses at germination and early growth stages. Pakistan Journal of Botany 40(6):2437-2441.

Raza SH, Athar HUR, Ashraf M (2006). Influence of exogenously applied gycinebetaine on the photosynthetic capacity of two differently adapted wheat cultivars under salt stress. Pakistan Journal of Botany 38(2):341351.

Rouhier N, Jacquot JP (2008). Getting sick may help plants overcome abiotic stress. New Phytologist 180(4):738-741.

Sabater B, Rodriquez MI (1978). Control of chlorophyll degradation in detached leaves of barley and oat through effect of kinetin on chlorophyllase levels. Physiologia Plantarum 43(3):274276.

Shannon MC, Grieve CN (1999). Tolerance of vegetables to salinity. Scientia Horticulturae 78:5-38.

Singh PK, Gautam S (2013). Role of salicylic acid on physiological and biochemical mechanism of salinity stress tolerance in plants. Acta Physiologia Plantarum 35(8):2345-2353.
Staff USSL (1954). US Salinity Lab. Diagnosis and Improvements of Saline and Alkali soils-USDA Handbook.

Strain HH, Svec WA (1966). Extraction, separation, estimation and isolation of chlorophylls. In: Vernon LP, Seely GR (Eds). The chlorophylls. Academic Press, New Yorkpp 21-66.

Steel RGD, Torrie JH, Dickey DA (1997). Principles and procedures of statistics. A bio-metrical approach. 3rd ed. New York (NY), McGraw Hill Book.

Wahid A, Masood I, Javed IUH, Rasul E (1999). Phenotypic flexibility as marker of sodium chloride tolerance in sunflower genotypes. Environmental and Experimental Botany 42(2):85-94.

Wang S, Liu P, Chen D, Yin L, Li H, Deng X(2015). Silicon enhanced salt tolerance by improving the root water uptake and decreasing the ion toxicity in cucumber. Frontiers in Plant Science 6(759):1-10.

Xu S, Li J, Zhang X, Wei H, Cui L (2006). Effects of heat acclimation pretreatment on changes of membrane lipid peroxidation, antioxidant metabolites, and ultrastructure of chloroplasts in two cool-season turfgrass species under heat stress. Environmental and Experimental Botany 56(3):274285.

Zhang JH, Liu YP, Pan QH, Zhan JC, Wang XQ, Huang WD (2006). Changes in membrane-associated H-ATPase activities and amounts in young grape plants during the cross adaptation to temperature stresses. PlantScience 170(4):768-777. 